\title{
Financialization of Non-financial Industries, United States, 1980-2006
}

\author{
Youn $\mathrm{Ki}^{1} \&$ Misung $\mathrm{Ahn}^{2}$ \\ ${ }^{1}$ Independent Researcher, West Chester Township, USA \\ ${ }^{2}$ Research Center, Samsung Securities, Seoul, South Korea \\ Correspondence: Youn Ki, Independent Researcher. Correspondence: 9709 McCauly Rd, West Chester Township, \\ OH 45241, USA. E-mail: younki1007@gmail.com
}

Received: July 18, 2020

Accepted: August 18, 2020

Online Published: September 3, 2020

doi:10.5430/rwe.v11n5p72

URL: https://doi.org/10.5430/rwe.v11n5p72

\begin{abstract}
Non-financial firms have become substantially dependent on financial revenues. However, the timing and intensity of financialization vary by industry. We investigate variation in the level of financialization among different non-financial industries in the United States from 1980 to 2006. We first illustrate how unique incidents and regulatory changes influenced different industries' financialization trajectories. We also conduct a statistical analysis to examine three types of industry-level determinants: profitability, uncertainty, and factor intensity. We find that these determinants have high explanatory power regarding interindustry variation in financialization. An industry-level analysis allows us to better understand the role of historical, institutional, and industrial factors in the financialization process which have been overlooked in structure-oriented research.
\end{abstract}

Keywords: financialization, non-financial industry, uncertainty, factor intensity

Financialization has drawn increasing attention from pundits and the public. It broadly refers to the increasing importance of financial actors, activities, and motives in the economy, as opposed to non-financial counterparts. It also encompasses diverse phenomena including non-financial firms' increasing financial investments, the shift in corporate governance favoring shareholders, and the encroachment of finance into the realms of everyday life (Epstein 2005; Krippner 2011; Zwan 2014). Although scholars initially focused on the structural shift underlying the phenomenon, recent studies increasingly pay attention to its multifaceted character. Some emphasize how different countries, reflecting their unique historical experiences and institutional arrangements, exhibit distinctive processes and patterns of financialization (Becker et al. 2010; Demir 2009; Akkemik and Özen 2014; Barradas and Lagoa 2017). Others stress heterogeneity in firm-level financialization, demonstrating how a firm's size, productive role, or industrial base affects its propensity to financialize and its investment decisions (Orhangazi 2008; Soener 2015).

This research expands the insights of studies that refuse to characterize financialization as a homogenizing force; instead, it emphasizes multifaceted character of financialization. It aims to delineate distinctive institutional and industrial contexts under which financialization occurs. In this paper, we examine one key aspect of contemporary financialization: namely, financialization of non-financial firms. In particular, we focus on growing dependence of non-financial firms on financial revenues such as interest, dividends, and capital gains, as opposed to productive incomes, over the past several decades. (Note 1) However, the timing and intensity of financialization vary by industry. We investigate variation in the level of financialization among different non-financial industries in the United States from 1980 to 2006 by relying on both qualitative and quantitative sources.

We first identify the patterns of industry-level financialization over time, suggesting that historical incidents and institutional shifts facilitated restructuring and financialization of some industries. To further investigate why some industries are more financialized than others, we conduct statistical analysis focusing on a set of industry-level determinants: profitability, uncertainty, and factor intensity. We find that these determinants have high explanatory power. Specifically, uncertainty at the industry level is positively associated with financialization of non-financial industries. That is, when unique events such as an oil shock and industry-specific deregulation significantly raise uncertainty in certain industries, the firms in the industry are more likely to purchase short-term, liquid financial assets. We also find that an industry's productive characteristics matter. Industries of higher capital intensity and higher skill intensity are more financialized. Industries with long-term investment horizons seem to be under high pressure to increase financial investment in order to generate quick profits. 
This research is a first serious attempt to empirically analyze the determinants of industry-level financialization. It contributes to recent efforts in the literature to highlight the multifaceted character of financialization by analyzing interindustry variation in financialization. Moreover, an industry-level analysis enables us to better comprehend the role of historical, institutional, and industrial factors in the financialization process. We emphasize that industry-level uncertainty, often resulting from historical and policy shifts, encourages non-financial industries to financialize. Also, industry-specific productive traits affect industries' inclination to financialize. We first discuss the financialization literature, and then provide our empirical findings.

\section{Financialization of Non-financial Industries}

The literature on financialization has identified that non-financial firms (NFFs) have become dependent upon and responsive to financial markets since the 1980s. They have expanded investment in financial assets, deriving a substantial part of revenue from interest, dividends, and capital gains, as opposed to productive income. At the same time, they increased payments to creditors and shareholders in the form of interest, dividend payouts and share buybacks. Financialization of NFFs has important implications for the economy and society, from real investment and economic growth to distributive justice (Stockhammer 2004; Orhangazi 2008; Demir 2009; Tomaskovic-Devey, Lin, and Meyers 2015; Kliman and Williams 2015; Seo, Kim, and Kim 2016; Barradas and Lagoa 2017; Watkins 2017; Davis 2018; Tori and Onaran 2018; Onaran, Stockhammer, and Grafl 2011; Lin and Tomaskovic-Devey 2013; Hein 2015; Zezza 2018).

Regarding the causes of financialization of NFFs, two explanations gained wide traction. The first one concerns the structural crisis that NFFs in advanced economies faced since the late 1970s. As profitability in the real sector declined, NFFs expanded financial investments in order to compensate for lackluster performance and to remain economically viable. Moreover, growing exchange rate volatility, intensified international competition, and financial deregulation raised macroeconomic uncertainty, encouraging these firms to replace long-term investment in plant and equipment with short-term financial maneuvers (Arrighi 1994; Crotty 2005; Epstein 2005). The second cause relates to the shift in corporate governance. Since the 1980s, "shareholder value" became a dominant management paradigm for corporations, which refers to the notion that maximizing the return to shareholders should be the foremost purpose of the firm. This new mantra has spurred corporate executives to change corporate practices from "retain and reinvest" to "downsize and distribute" in attempts to placate impatient shareholders and Wall Street. The imperative of quick profits drove managers to prioritize financial investments over long-term investment and growth (Lazonick and O'Sullivan 2000; Stockhammer 2005; G. F. Davis 2009).

Although we now have well-developed theories on the causes of NFFs' financialization, empirical research on the subject is limited. This paper responds to the recent call for empirical research on the determinants of financialization of NFFs (Barradas and Lagoa 2017: 342; Davis 2017: 1339; Tori and Onaran 2018: 1411). To the best of our knowledge, only a small number of studies have empirically tested the determinants of financialization of NFFs. To begin with, Baud and Durand (2012) examine why 10 leading retailers such as Wal-Mart and Carrefour increased financial investment over the period of the 1990s up until 2007. They claim that a slowdown of these retailers' growth in domestic markets led them first to internationalize, and then to financialize. As such, they support the thesis that a profitability crisis in the real sector is a key factor behind financialization of NFFs.

Other empirical studies similarly address structural shifts, yet put more emphasis on heterogeneity of financialization of NFFs. Akkemik and Özen (2014) examine financialization of NFFs in Turkey, underscoring how a country's unique historical and institutional features influence financialization. The Turkish economy has been highly exposed to macroeconomic shocks and uncertainties since the 1980s due to the conflation of liberalization, increased public sector borrowing, and the stabilization program under the auspices of the International Monetary Fund. Their analysis of 41 firms listed on the Istanbul Stock Exchange for the period 1990-2002 shows that macroeconomic uncertainty led Turkish NFFs to increase financial investment. This finding is consistent with observations that financial liberalization both raises macroeconomic volatility and increases NFFs' opportunities to make financial investments, often in developing and emerging market economies (Firat Demir 2009a; Firat Demir 2009b; Seo, Kim, and Kim 2016).

Also, drawing on the institutional literature, Akkemik and Özen delve into peculiar characters of the Turkish business system. Business systems, according to them, are "distinctive patterns of economic organization that vary in degree and mode of authoritative coordination of economic activities at the national level" (Akkemik and Özen 2014: 80). In the Turkish institutional environment, the biggest business groups have special and strong relations with political and bureaucratic elites. Also, the state produces both risks and opportunities critical for business operations not only through policymaking but also via arbitrary interventions and preferential treatment by political 
patronage. Specifically, they investigate how such factors as firms' ties with the government, family ownership, and unionization affect financialization, showing that these factors are not conducive to financialization.

Soener's (2015) study of 173 American firms in the retail, apparel, and footwear industry spanning 1991 to 2005 contends that a firm's propensity to financialize hinges on its productive roles. He explores the relationship between financialization and different supply chain types in global production networks, such as branded marketer, branded manufacturer, general retailer, and special retailer. He finds a noticeable variation across supply chain types. Branded marketers and manufacturers are much more financialized than retailers and textile producers. Branded marketers such as Nike focus on marketing, design, and brand imaging, making them far less capital and labor intensive than other supply types. Their heavy reliance on intangible assets allows them to easily recycle revenue into financial investment. Conversely, retailers like Target and Wal-Mart have less room to financialize because it is imperative for them to expand productive operations such as opening and updating stores to remain competitive.

Another interesting finding of Soener's (2015) study is that firms learn to financialize from other firms in the same industry. He tests the neoinstitutionalist theory which claims that social norms shape our reality and practices. Certain practices become institutionalized as actors imitate others within the social field (mimetic isomorphism) or as experts transmit knowledge and practices (normative isomorphism). He conceptualizes an industry as a social field and examines the relationship between industry-level financialization and firm-level financialization. He finds a significant and positive association between them. If the total level of financial assets increases in the industry, a firm will also increase its level of financial assets. That is, socialization matters.

Building on the recent efforts to shed light on divergent financialization behaviors, we examine how industry-level dynamics shape the financialization process. Specifically, we aim to explain a variation in the degrees of financialization across non-financial industries in the United States with a focus on industry-level determinants: industry-level profitability, industry-level uncertainty, and industry-level factor intensity. Given how peculiar historical, institutional, and productive contexts substantially influence firm practices, it is imperative to explore industry-level variables. Most notably, a great number of historical events and policy shifts are industry-specific, affecting some industries' profitability and profit volatility but not others. (Note 2) For instance, the 1973 OPEC embargo and the 1978-1979 Iranian oil-export cutoff produced price volatility that caused restructuring and consolidation in oil-related industries. Deregulation and reregulation initiatives, trade negotiations, and protectionist measures also are often industry-focused. Industrial policies, by definition, selectively target certain sectors in order to improve their competitiveness in world markets. An industry-level analysis will draw attention to important historical and institutional factors in the financialization process which have been underestimated in structure-oriented studies.

Moreover, distinctive productive characteristics seem to induce certain industries to react to an economywide change differently from other industries. Soener's (2015) study demonstrates that an industry's productive roles and capabilities facilitate or hinder the industry's financialization. Branded marketers, being less capital and labor intensive than others such as retailers, are better positioned to recycle revenue into financial investment. As such, he concludes that "we cannot understand financialization without understanding production" (Soener 2015: 549). His intriguing findings, which narrowly focus on America's apparel and footwear industry, encourage us to apply his insight to a broader array of industries. In this paper we empirically test the relationship between financialization and three types of industry-level factor intensity: physical capital intensity, human capital intensity, and energy intensity.

This paper contributes to the literature in three important ways. First, it is the first research to systematically analyze industry-level determinants of financialization. Scholars have noticed significant variation in the degree of financialization across different industries. For instance, Lin and Tomaskovic-Devey (2013) identify a significant variance with regard to the degree and pattern of financialization among 35 different industries from 1970 to 1997 , and 40 industries from 1998 to 2008 in the United States. They state that tobacco, motor vehicles, oil and gas extraction, and communications showed the greatest financialization growth between 1970 and 1997. However, they do not explain why some industries are more financialized than others. This study aims to fill the gap by tracing historical patterns of financialization of non-financial industries in the United States from 1980 to 2006. We also conduct a statistical analysis to examine three types of industry-level determinants: profitability, uncertainty, and factor intensity.

Second, we offer a comprehensive and detailed picture of financialization of non-financial industries by utilizing both qualitative and quantitative data. We rely on primary sources to discuss a few selected industries' financialization in the broader economic and political contexts. Moreover, our statistical research uses three different 
data sets: Compustat (407 industries), IRS (55 industries for 1980-1997, 67 for 1998-2001, and 71 for 2001-2006), and NBER-CES (136 industries, manufacturing sector only).

Ultimately, this research speaks to the recent studies that emphasize multifaceted characters of financialization. Specifically, an industry-level analysis enables us to highlight historical and institutional environments under which non-financial industries' financialization unfolds. It also demonstrates how production-related traits mediate totalizing forces, generating diverse financialization outcomes.

\section{Patterns of Financialization of Non-financial Industries: Historical Analysis}

We start with an overview of industry-level financialization from 1980 to 2006 in the United States. (Note 3) We focus on the period when the American economy underwent dramatic financial shifts, leading up to the 2007 financial crisis. This section tracks financial income of non-financial industries using the IRS data. Following Krippner's (2011) conceptualization, we calculate financialization as the ratio of financial receipts to business receipts. (Note 4) Financial receipts include interest, dividends, and capital gains. The IRS data is based on tax reports and therefore provides reliable and comprehensive information, representing millions of firms of various sizes. For instance, in 1980, it covered 2.2 million non-financial firms, and the firms' total assets were approximately $\$ 3.6$ trillion; in 2006, it covered 5.6 million non-financial firms, and their assets totaled approximately $\$ 38$ trillion.

Figure 1 and 2 visualize different financial trajectories of nonfinance industries at the high level of aggregation (nine "major" industries in IRS classification). The most striking pattern is that mining, manufacturing, communication, and utilities show high and fluctuating financialization levels (Figure 1), while agriculture, construction, transportation, wholesale and retail trades, and services demonstrate relatively low and stable levels (Figure 2). Throughout the entire period mining showed a high degree of financialization, although it was more financialized in the first half than in the latter half. Similarly, manufacturing was highly financialized over the past several decades, as many scholars have indicated. Communications was one of the least financialized industries in the early 1980s, but rapidly increased the share of financial income beginning in the mid-1980s. After a short period of stagnation in the early 1990s, its financial income started to soar in the mid-1990s, making it the most financialized industry in the late 1990s and early 2000s. Utilities demonstrated a trajectory similar to communications during the same time period, although its financial expansion was much more moderate than that of communications.

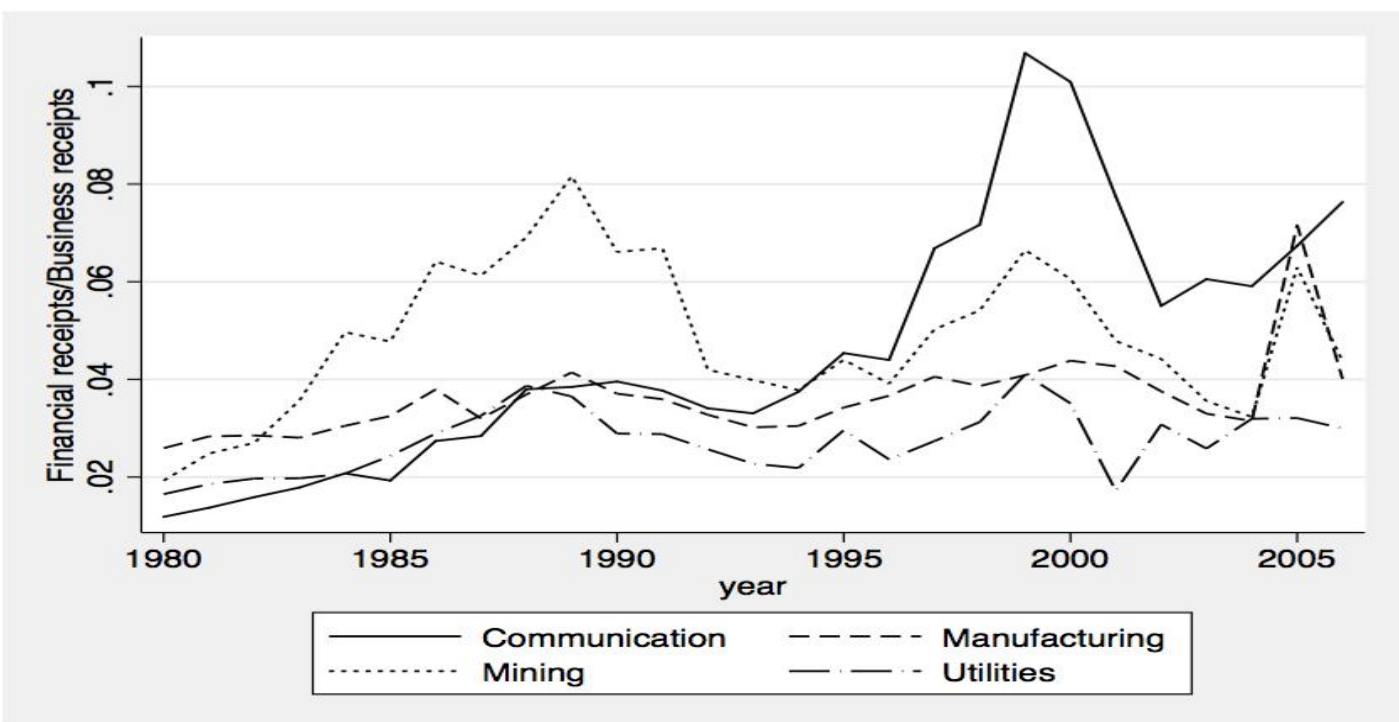

Figure 1. Financialization across industries ("major" industries): Highly financialized industries

Source: IRS 


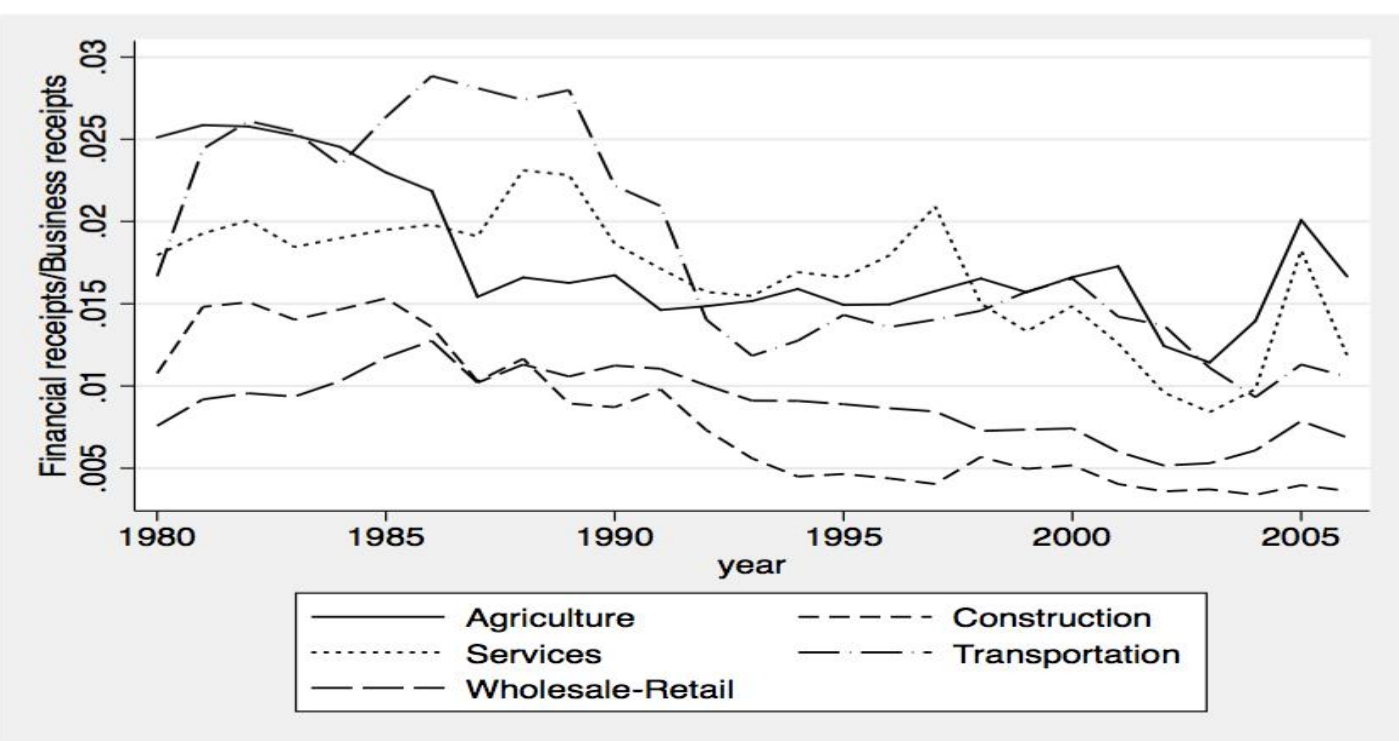

Figure 2. Financialization across industries (“major" industries): Less financialized industries

Source: IRS

What, then, explains different patterns of financializaton of non-financial industries? Studies of financialization have suggested the importance of uncertainty in explaining NFFs' financialization (Arrighi 1994; Crotty 2005; Epstein 2005; Demir 2009; Krippner 2011; Akkemik and Özen 2014). However, they have mostly focused on macroeconomic uncertainty, underestimating the extent to which industry-specific shocks influenced NFFs' investment decisions. Conversely, we investigate the relationship between industry-level volatility and financialization. Our anecdotal evidence suggests that most financialized industries largely coincide with those that experienced vigorous restructuring through mergers, acquisitions, and divestitures over the period from 1980 to 2006.

For instance, the oil industry, chemical manufacturing, and motor vehicle manufacturing were the most financialized industries, and the most active in restructuring in the 1980s. Table 1 shows the seven most financialized industries between 1985 and 1989, using the low level of aggregation ("minor" industry in IRS classification). Within the mining industry, metal mining and oil and gas extraction show particularly higher financialization tendencies than others during this period. Also, tobacco manufacturing, chemicals and allied products manufacturing, petroleum and coal products manufacturing, machinery manufacturing and motor vehicles and equipment manufacturing stand out. Interestingly, we find a substantial overlap across the lists of financialization and restructuring. As Table 2 shows, crude petroleum and natural gas, petroleum and coal manufacturing, motor vehicle manufacturing, drug manufacturing, and industrial chemical manufacturing were the most active non-financial industries in mergers and acquisitions between 1979 and 1989. Also, the oil industry and chemical manufacturing, along with communications industry, experienced the largest divestitures in 1985 (Table 3).

Table 1. Most financialized industries (“minor" industries), 1985-1989

Financialization (Financial receipts/Business receipts)

\begin{tabular}{lllll}
\hline 1985 & 1986 & 1987 & 1988 & 1989 \\
\hline $5 \%$ & $7 \%$ & $13 \%$ & $13 \%$ & $9 \%$ \\
$6 \%$ & $8 \%$ & $7 \%$ & $8 \%$ & $11 \%$ \\
\hline
\end{tabular}




\begin{tabular}{|c|c|c|c|c|c|}
\hline \multicolumn{6}{|l|}{ Manufacturing } \\
\hline Tobacco & $5 \%$ & $3 \%$ & $4 \%$ & $9 \%$ & $11 \%$ \\
\hline $\begin{array}{l}\text { Chemicals and allied } \\
\text { products }\end{array}$ & $4 \%$ & $5 \%$ & $5 \%$ & $4 \%$ & $4 \%$ \\
\hline $\begin{array}{l}\text { Petroleum and coal } \\
\text { products }\end{array}$ & $4 \%$ & $6 \%$ & $5 \%$ & $4 \%$ & $5 \%$ \\
\hline Machinery & $5 \%$ & $5 \%$ & $4 \%$ & $6 \%$ & $5 \%$ \\
\hline $\begin{array}{l}\text { Motor vehicles and } \\
\text { equipment }\end{array}$ & $4 \%$ & $5 \%$ & $4 \%$ & $7 \%$ & $11 \%$ \\
\hline
\end{tabular}

Source: IRS

Table 2. Industries most active in acquisitions, 1979-89, excluding financial industries

Industries Most Active as Acquirers, 1979-89, Value in Millions 1987 Dollars
Industries Most Heavily Targeted for Acquisitions, 1979-89, Value in Millions 1987 Dollars

\begin{tabular}{|c|c|c|c|c|c|}
\hline Ranked by value & Number & Value & Ranked by value & Number & Value \\
\hline Crude Petroleum, Natural Gas & 195 & 63,401 & Crude Petroleum, Natural Gas & 172 & 77,999 \\
\hline Petroleum \& Coal Prods. & 40 & 36,223 & Drugs & 76 & 46,886 \\
\hline Motor Vehicles \& Equipment & 91 & 36,044 & $\begin{array}{l}\text { Food Prods, Except Grain Mill } \\
\text { Prods. }\end{array}$ & 122 & 46,725 \\
\hline Drugs & 109 & 30,441 & Radio \& Television Broadcasting & 249 & 30,252 \\
\hline $\begin{array}{l}\text { Food Prods, Except Grain Mill } \\
\text { Prods. }\end{array}$ & 134 & 29,612 & Business Services & 287 & 24,791 \\
\hline Industrial Chemicals & 101 & 28,133 & $\begin{array}{l}\text { Electric, Gas, \& Sanitary } \\
\text { Services }\end{array}$ & 83 & 23,694 \\
\hline
\end{tabular}

Blair and Uppal 1993: 47, 50

Table 3. 40 largest divestitures in 1985, excluding financial firms 40 Largest Divestitures in 1985, Value in Millions 1985 Dollars

\begin{tabular}{lclrlr}
\hline Ranked by Value & \multicolumn{1}{l}{ Price } & Ranked by Value & Price & Ranked by Value & Price \\
\hline Chevron & 2,042 & IBM & 459 & Sperry Corp. & 330 \\
Allied & 1,700 & Champion International & 457 & Kidde & 300 \\
Westinghouse & 1,600 & Metromedia & 450 & Monsanto & 300 \\
Occidental Petroleum & 1,035 & Ralston Purina & 450 & Purex Industries & 264 \\
United Technologies & 1,000 & Goodyear Tire \& Rubber & 446 & Rapid American & 260
\end{tabular}




\begin{tabular}{|c|c|c|c|c|}
\hline Gulf \& Western & 1,000 & Atlantic Richfield & 420 & $\begin{array}{l}\text { Des Moines Register \& } \\
\text { Tribune }\end{array}$ \\
\hline Gulf Broadcast Co. & 760 & Armco & 415 & Transworld Corp \\
\hline Pan Am & 750 & Pantry Pride & 395 & Internorth \\
\hline Monsanto & 745 & Holiday Corp. & 390 & Cannon Mills \\
\hline Pantry Pride & 690 & Warner Communications & 387 & $\begin{array}{l}\text { Capital Cities } \\
\text { Communications }\end{array}$ \\
\hline Avon Products & 675 & Ogden Corp & 375 & Kaneb Services \\
\hline Metromedia & 650 & ITT Corp & 370 & Tribune Co. \\
\hline RCA & 587 & $\begin{array}{l}\text { Capital Cities } \\
\text { Communications }\end{array}$ & 350 & Union Carbide \\
\hline $\begin{array}{l}\text { Golden West Television } \\
\text { Holding Co. }\end{array}$ & 510 & & & \\
\hline
\end{tabular}

Source: Mergerstat 1985

In a similar vein, the communications industry was the leader in both financialization and restructuring in the late 1990s and early 2000s. The IRS began to offer four subindustries since 1998: publishing, motion pictures and sound recording, broadcasting and telecommunications, and information services and data processing. The IRS record shows that all four subindustries of the communication sector were highly financialized in the late 1990s and early 2000s. Intriguingly, communications and broadcasting were also the most active industries in mergers and acquisitions in the late 1990s (Mergerstat 1997: 57). They maintained their position as restructuring leaders throughout the late 1990s and early 2000s (Table 4). Moreover, the utilities sector demonstrated a similar pattern. It was one of the more financialized "major" industries in the late 1990s and early 2000s. (Figure 1); at the same time, it was highly active in mergers and acquisitions (Table 4).

Table 4. Industries most active in mergers and acquisitions, 1999-2003

\begin{tabular}{cccccr}
\hline \multicolumn{5}{c}{ Industries Most Active in M\&As, by Dollar Value Offered (in millions, nominal) } \\
\hline & 1999 & 2000 & 2001 & 2002 & 4-year Average \\
\hline Communications & 304,940 & 85,140 & 20,295 & 26,336 & 109,178 \\
\hline Broadcasting & 171,644 & 43,144 & 114,425 & 13,842 & 85,764 \\
\hline $\begin{array}{c}\text { Computer Software, } \\
\text { Supplies \& Services }\end{array}$ & 119,467 & 144,595 & 32,454 & 25,496 & 80,503 \\
\hline $\begin{array}{c}\text { Drugs, Medical Supplies \& } \\
\text { Equipment }\end{array}$ & 128,284 & 31,051 & 61,062 & 69,978 & 72,594 \\
\hline $\begin{array}{c}\text { Electric, Gas, Water \& } \\
\text { Sanitary Services }\end{array}$ & 86,385 & 53,980 & 18,541 & 22,491 & 45,349 \\
\hline Oil \&Gas & 37,348 & 67,202 & 51,264 & 10,338 & 41,538 \\
\hline Electrical Equipment & 49,131 & 53,949 & 32,893 & 8,593 & 36,142 \\
\hline
\end{tabular}

Mergerstat 2004: 69

Our historical research suggests the importance of industry-specific shocks in inducing non-financial firms to take dramatic steps such as financialization and restructuring. The rest of the section briefly discusses the experiences of a 
few industries in this light: oil, chemical manufacturing, and communications. To begin with, the oil industry experienced perhaps the most violent transformations among American industries in the late 1970s and 1980s. Changes in petroleum prices catalyzed large-scale restructuring in energy sectors. A positive wealth shock in the oil industry first encouraged oil firms to indulge in the acquisition craze. However, the indulgence did not last long. Soon, the decline of oil prices made these firms major targets for consolidation. Indeed, the number of oil-related merger activities rose from approximately $10 \%$ to one third of all mergers and acquisitions between 1979 and 1984 (Wigmore 1997: 301-2). Extreme volatility in the oil sector might have induced firms to use financial assets as a hedging tool that could offer them additional cash flow. Moreover, certain restructurings such as mergers, acquisitions, and divestitures can boost financial income of a firm, albeit temporarily. (Note 5)

Chemicals manufacturing also went through significant restructuring in the 1980s. It exited from heavily "commodified" chemicals businesses en masse, after being severely hit by energy crises and foreign imports. The value of divestitures in chemicals manufacturing grew tenfold from $\$ 233$ million in 1980 to $\$ 2.8$ billion in 1986 . The factories deserted by large chemical companies were bought by new smaller chemical firms (Lane 1993: 241-56). At the same time, the big four-Dow, DuPont, Monsanto, and Union Carbide—redirected resources into new specialty chemicals and other high value-added fields. For example, Monsanto's aggressive ten-year expansion into engineering, biological sciences, and agriculture culminated in the acquisition of G.D. Searle for \$2.7 billion in 1985 (WSJ 7/21/1978; WSJ 12/20/1979; Washington Post 7/19/1985). The unprecedented uncertainty in the chemical industry may partially explain the high level of financialization of chemical manufacturing.

The communications sector, which became the most financialized non-financial industry by the mid-1990s, has a roller-coaster history due to regulatory policy shifts. Before the mid-1990s, the Federal Communications Commission (FCC) prohibited any one company from owning a specified number of AM and FM radio and television stations. Accordingly, broadcasting companies that were wanting to acquire other operations had to divest stations to comply with the FCC rule, thereby engaging in a flurry of transactions (Mergerstat 1985: 99). In 1996, Congress passed the Telecommunications Act which loosened restrictions on ownership of radio and television stations, inducing reshuffling of media ownership. The communications and broadcasting industry quickly became the most active industry in mergers and acquisitions by 1997 (Mergerstat 1997: 57).

This section has illustrated the substantial overlap between most financialized industries and the industries that were most active in mergers and acquisitions over the 1980s and 1990s. Our historical observation, albeit preliminary, suggests a potential positive relationship between industry-level uncertainty and financialization. The next section utilizes quantitative data to closely investigate the relationship. Additionally, it tests other factors such as industry-level profitability and factor intensity.

\section{Determinants of Interindustry Variation of Financialization: Quantitative Analysis}

In the previous sections, we provided the theoretical and historical rationale behind our industry-level analysis. This section conducts a statistical analysis of industry-level determinants of financialization.

\subsection{Data and Methodology}

We collected time-series, cross-sectional data from 1980 to 2006 to analyze financialization of non-financial industries in the United States. Variables are drawn from two sources: Compustat and NBER-CES database. Compustat allows us to better examine the determinants of industry-level financialization than IRS sources for two main reasons. First, it provides detailed information of 407 industries, while IRS provides aggregated outlooks of 55-70 industries ("minor" industries). Second, Compustat completely tracks each firm over time, offering a coherent and consistent picture. Conversely, IRS has changed its classification several times, making it hard to conduct a well-controlled statistical study. (Note 6) We also use the NBER-CES Manufacturing Industry Database, which is a joint effort between the National Bureau of Economic Research (NBER) and U.S. Census Bureau's Center for Economic Studies (CES). It contains annual industry-level data (136 manufacturing industries) on output, employment, payroll and other input costs, investment, capital stocks, TFP, and various industry-specific price indexes. We induce factor intensities from this NBER-CES data.

This study primarily uses longitudinal techniques. Since our goal is to evaluate the extent of industry financialization caused by industry-level profitability, uncertainty, and factor intensity, we need to control other variables that may spuriously drive the relationships. We achieve this in three ways. First, we wash out individual firm idiosyncrasies within an industry by taking an average of each variable across all the firms in that industry. We treat this single hypothetical firm as a representative firm in each industry. This method controls firm heterogeneity. Second, we include industry and time fixed effects in all specifications throughout this paper. The fixed effects model holds 
constant another potential source of distortion from industry and year heterogeneity. We intend to control, for instance, increased financialization due to regulation or policy changes in a certain year or industry that might be correlated with industry profitability or uncertainty. Lastly, following the convention, all standard errors are adjusted for the unrestricted forms of heterogeneity.

In our statistical analysis of industry-driven determinants of financialization, the dependent variable is financial assets of a non-financial industry, which consist of cash and short-term investments, receivables, current and other assets, and investment and advances. (Note 7) We use Compustat to investigate 407 non-financial industries. We control for industry size by logged total sales - a value that is positively related with financial assets (Table 6). (Note 8) This specification ensures the relationship to be valid after controlling for the mechanical proportional increase of financial investment with increase of sales. Mathematically, our baseline specification is:

$$
\ln F_{i, t}=\alpha_{0}+\alpha_{1} \ln S_{i, t}+\alpha_{2} \ln X_{i, s}+I_{i}+T_{t}++\varepsilon_{i, t}
$$

where $F_{i, t}$ is financial assets of industry $i$ at time $t, S_{i, t}$ is sales of industry $i$ at time $t, X_{i}$ is covariates of interest of industry $i$ at various time $s$ where all variables are natural log-transformed. $I_{i}$ captures industry fixed effects and $T_{t}$ captures year fixed effects.

We aim to explain why some industries are more financialized than others. We first test the effects of profitability and uncertainty on financialization. As for profitability, we use two measures from income statements: gross profit and operating income. While the former represents the industry's overall profit, the latter indicates profits specifically derived from non-financial activities. As for uncertainty, we calculate the standard deviations of each profit measure of $\mathrm{t}-1, \mathrm{t}-2$, and $\mathrm{t}-3$ years. That is, we are interested in the question of whether uncertainty in industry-level profits influences the industry's financialization or not. (Note 9)

Next, we assess the effect of factor intensity, focusing on the manufacturing sector. Using the NBER-CES dataset, we investigate three types of factor intensity: human capital intensity, physical capital intensity, and energy intensity. For human capital intensity, we use two measures: the share of number of nonproduction workers in total employment and the share of income of nonproduction workers in total payroll. For physical capital intensity, we use three measures: the ratio between capital stock and total value added, the ratio between capital stock and the number of total workers, and the ratio between capital stock and the total payroll. For energy intensity, we use two measures: the share of energy costs in total production costs and a dummy variable which is 1 when the share of energy costs in total production costs is larger than $10 \%$, and 0 otherwise. Major variables are summarized in Table 5 .

Table 5. List of variables

\begin{tabular}{|c|c|}
\hline Variable & Description \\
\hline Financial assets & $\begin{array}{l}\text { Cash and short-term investments, receivables, current and other assets, investment and } \\
\text { advances (Compustat items CHE, RECT, IVAEQ, IVAO, ACO, AO) }\end{array}$ \\
\hline Profit & Gross Profit (Compustat item GP) \\
\hline Operating income & Operating income before depreciation (Compustat item OIBDP) \\
\hline Profit uncertainty & Standard deviations of profit of the past three $(\mathrm{t}-1, \mathrm{t}-2, \mathrm{t}-3)$ years \\
\hline $\begin{array}{l}\text { Operating income } \\
\text { uncertainty }\end{array}$ & Standard deviations of operating income of the past three $(\mathrm{t}-1, \mathrm{t}-2, \mathrm{t}-3)$ years \\
\hline $\begin{array}{l}\text { Human capital } \\
\text { intensity }\end{array}$ & $\begin{array}{l}\text { - The share of income of nonproduction workers in total payroll } \\
\text { - The share of number of nonproduction workers in total employment }\end{array}$ \\
\hline $\begin{array}{l}\text { Physical capital } \\
\text { intensity }\end{array}$ & $\begin{array}{l}\text { - The ratio between capital stock and total value added } \\
\text { - The ratio between capital stock and the number of total workers } \\
\text { - The ratio between capital stock and the total payroll }\end{array}$ \\
\hline
\end{tabular}


Energy intensity
- The share of energy costs in total production costs including energy (electric and fuels), total payroll, total value of shipment, total materials, and capital expenditure

- Dummy variable which is 1 when the share of energy costs in total production costs is larger than $10 \%$, and 0 otherwise

\subsection{Results and Discussion}

The results are shown in Tables 6 and 7. Contrary to the conventional wisdom, both measures of profit are positively correlated with financialization and statistically significant (Columns 1 and 7 in Table 7). Moreover, industries that earned higher operating profits are more likely to increase financial investment in the following year than the industries with lower profits. Specifically, $1 \%$ increase in this year's operating profit is correlated with $0.14 \%$ increase in financial investment (Column 7 in Table 7). The degree of association between the last year's operating profit and financial investment becomes less pronounced but still remains positive to $0.10 \%$ (Column 8 in Table 7). All estimates are statistically significant at the $1 \%$ level. This is striking because financialization studies have theorized that financialization occurs due to lack of profit opportunities in the "real" sector. Many studies have assumed substitutability of real and financial assets such that changes in profitability could drive a portfolio reallocation. That is, an increase in operating profits may traditionally be expected to generate a portfolio reallocation towards real investments, thereby depressing NFFs' acquisition of financial assets. However, our statistical analysis shows that real profits are positively associated with financialization at the industry level.

We reason that boosted operational earnings means deeper pools of available funds, which can increase holding of both physical and financial assets in succeeding years. As Davis (2017: 1342) suggests, "there is no priori reason" to assume that additional funds will be allocated entirely towards acquisition of fixed assets, much less cause a decrease in financial acquisitions. It is also possible that higher industry-level profitability raises a firm's positive economic outlook, subsequently fostering both productive and financial operations. Furthermore, our finding is consistent with the recent observations that a potential trade-off between real and financial investments hinges on credit constraints (Kliman and Williams 2015; Davis 2017).

If a firm has easy access to external finance, it does not need to choose between different types of assets. According to this logic, industries with higher profits may be able to borrow funds more cheaply and easily, which in turn facilitates investments of any kind. (Note 10)

The signs of uncertainty coefficients are positive for both gross profit and operating income. After controlling for the level of profitability in addition to the level of sales, the variability of gross profits shows positive correlation with financialization at a 5\% level of statistical significance (Column 6 in Table 7). Conditional on the size and profitability of the prior year, a $1 \%$ increase in the past three years' standard deviation of gross profits, the financial investment rises by $0.014 \%$. The variability of operating profits has a higher impact with the estimated effect of $0.091 \%$ on financialization at a $1 \%$ level of statistical significance (Column 11 in Table 7). The results show that an industry with higher profit uncertainty tends to make more financial investment. In particular, uncertainty in "real" profits seems to be a better predictor of financialization than overall profit variability. This result confirms the dominant narrative that firms would prefer investment in liquid financial assets over long-term fixed capital investments in times of high uncertainty. Also, financial profits work as a hedging mechanism that provide firms with extra cash flows to weather the storm (Demir 2009). Furthermore, this statistical result is in line with our historical analysis in the previous section on the positive relationship between industry-level uncertainty and financialization.

Table 8 demonstrates the relationship between factor intensity and financialization in manufacturing industries. We find that a capital-intensive industry is more financialized than a labor-intensive industry. The finding is statistically significant in all three measures of capital intensity. We also find that industries with high-skilled workers are more financialized than industries with low-skilled workers. The magnitude and statistical significance of the relationship is higher when human capital intensity is defined as the sum of factor returns than the quantity of factors (i.e., number of employees). We reason that managers of capital-intensive industries and skill-intensive industries might be under great pressure to expand liquid, short-term financial investments in order to mitigate inherent risks of long-term and irreversible capital investments. Increased macroeconomic uncertainty since the 1980s may have encouraged corporate treasurers to purchase financial products to balance out illiquid investments in tangible assets such as plant and equipment or intangible assets such as research and development. Since R\&D investments have a 
longer time horizon than ordinary investments (Hall 1994), managers in skill-intensive industries will also make a similar decision. Furthermore, the ascendance of the shareholder value idea has driven corporate executives to focus on short-term profitability over long-term measures of firm performance and growth. Under that circumstance, managers are less inclined to tie up funds in long-term, irreversible investments, instead increasing financial activities in attempts to placate impatient shareholders and Wall Street. Our findings imply that managers in some industries may be under higher pressure to do so than others.

Lastly, our statistical analysis shows that energy-intensive industries are less financialized than industries with less energy dependency. The finding is statistically significant when we use a dummy variable, which is 1 when the share of energy costs in total production costs is larger than $10 \%$, and 0 otherwise. When measured by the share of energy costs in total production costs, energy intensity still is negative associated with financialization, albeit with lower statistical significance. Generally, energy-intensive manufacturing includes food, pulp and paper, basic chemicals, refining, iron and steel, nonferrous metals, and nonmetallic minerals, whereas nonenergy-intensive manufacturing includes fabricated metal products, machinery, computer and electronic products, transportation equipment, electrical equipment, and "other" chemicals such as pharmaceuticals, paint and coatings, and adhesives. According to U.S. Energy Information Administration's International Energy Outlook, advanced economies including the United States have moved away from energy-intensive manufacturing, while emerging economies have increased it (U.S. Department of Energy 2016). Domestic resistance to high energy consumption and tight international competition might have squeezed profits in energy-intensive manufacturing. Given our findings on the positive relationship between profits and financialization, industries with higher energy dependency may have had less capacity to increase financial assets than industries with lower energy dependency.

Table 6. Employment and sales

\begin{tabular}{|c|c|c|c|c|c|c|c|c|c|c|}
\hline & (1) & (2) & (3) & $\begin{array}{l}\text { (4) } \\
\text { Dependent }\end{array}$ & $\begin{array}{l}\text { (5) } \\
\text { ariable: } \log \end{array}$ & $\begin{array}{l}\text { (6) } \\
\text { (Financial }\end{array}$ & $\begin{array}{l}\text { (7) } \\
\text { sets at time } t)\end{array}$ & (8) & (9) & (10) \\
\hline $\begin{array}{l}\log (\text { Number of } \\
\text { employees at time } t)\end{array}$ & $\begin{array}{l}0.696 * * * \\
(0.0144)\end{array}$ & & & & & & & & & \\
\hline $\begin{array}{l}\log (\text { Number of } \\
\text { employees at time } t-1)\end{array}$ & & $\begin{array}{l}0.628 * * * \\
(0.0129)\end{array}$ & & & & & & & & \\
\hline $\begin{array}{l}\log (\text { Number of } \\
\text { employees at time } t-2)\end{array}$ & & & $\begin{array}{l}0.555 * * * \\
(0.0133)\end{array}$ & & & & & & & \\
\hline $\begin{array}{l}\log (\text { Number of } \\
\text { employees at time } t-3)\end{array}$ & & & & $\begin{array}{l}0.468 * * * \\
(0.0130)\end{array}$ & & & & & & \\
\hline $\begin{array}{l}\text { Standard Deviation of } \\
\text { the Number of } \\
\text { Employees from the } \\
\text { last three years }\end{array}$ & & & & & $\begin{array}{l}-0.319 * * * \\
(0.0762)\end{array}$ & & & & & \\
\hline $\log ($ Sales at time $t)$ & & & & & & $\begin{array}{l}0.894 * * * \\
(0.0150)\end{array}$ & & & & \\
\hline $\log ($ Sales at time $t-1)$ & & & & & & & $\begin{array}{l}0.817 * * * \\
(0.0122)\end{array}$ & & & \\
\hline $\log ($ Sales at time $t-2)$ & & & & & & & & $\begin{array}{l}0.729 * * * \\
(0.0126)\end{array}$ & & \\
\hline $\log ($ Sales at time t-3) & & & & & & & & & $\begin{array}{l}0.632 * * * \\
(0.0126)\end{array}$ & \\
\hline $\begin{array}{l}\text { Standard Deviation of } \\
\text { Sales } \\
\text { from the last three }\end{array}$ & & & & & & & & & & $\begin{array}{l}-0.465 * * * \\
(0.0940)\end{array}$ \\
\hline
\end{tabular}




\begin{tabular}{|c|c|c|c|c|c|c|c|c|c|c|}
\hline years & & & & & & & & & & \\
\hline Constant & $\begin{array}{l}2.305 * * * \\
(0.0636)\end{array}$ & $\begin{array}{l}2.455 * * * \\
(0.0652)\end{array}$ & $\begin{array}{l}2.631 * * * \\
(0.0702)\end{array}$ & $\begin{array}{l}3.264 * * * \\
(0.0897)\end{array}$ & $\begin{array}{l}3.894 * * * \\
(0.0961)\end{array}$ & $\begin{array}{l}-0.840 * * * \\
(0.0930)\end{array}$ & $\begin{array}{l}-0.368 * * * \\
(0.0836)\end{array}$ & $\begin{array}{l}0.0966 \\
(0.0882)\end{array}$ & $\begin{array}{l}1.000 * * * \\
(0.107)\end{array}$ & $\begin{array}{l}3.933 * * * \\
(0.0954)\end{array}$ \\
\hline $\begin{array}{l}\text { Number of } \\
\text { Observations }\end{array}$ & 13351 & 13358 & 13366 & 13387 & 13379 & 13382 & 13378 & 13383 & 13387 & 13385 \\
\hline R-squared & 0.916 & 0.895 & 0.880 & 0.865 & 0.831 & 0.952 & 0.924 & 0.901 & 0.882 & 0.832 \\
\hline
\end{tabular}

Note: Industry fixed effects and year fixed effects are included in all specifications in this table.

Standard errors in parentheses, * $\mathrm{p}<0.05 * * \mathrm{p}<0.01 \quad * * * \mathrm{p}<0.001$

Table 7. Profit and uncertainty

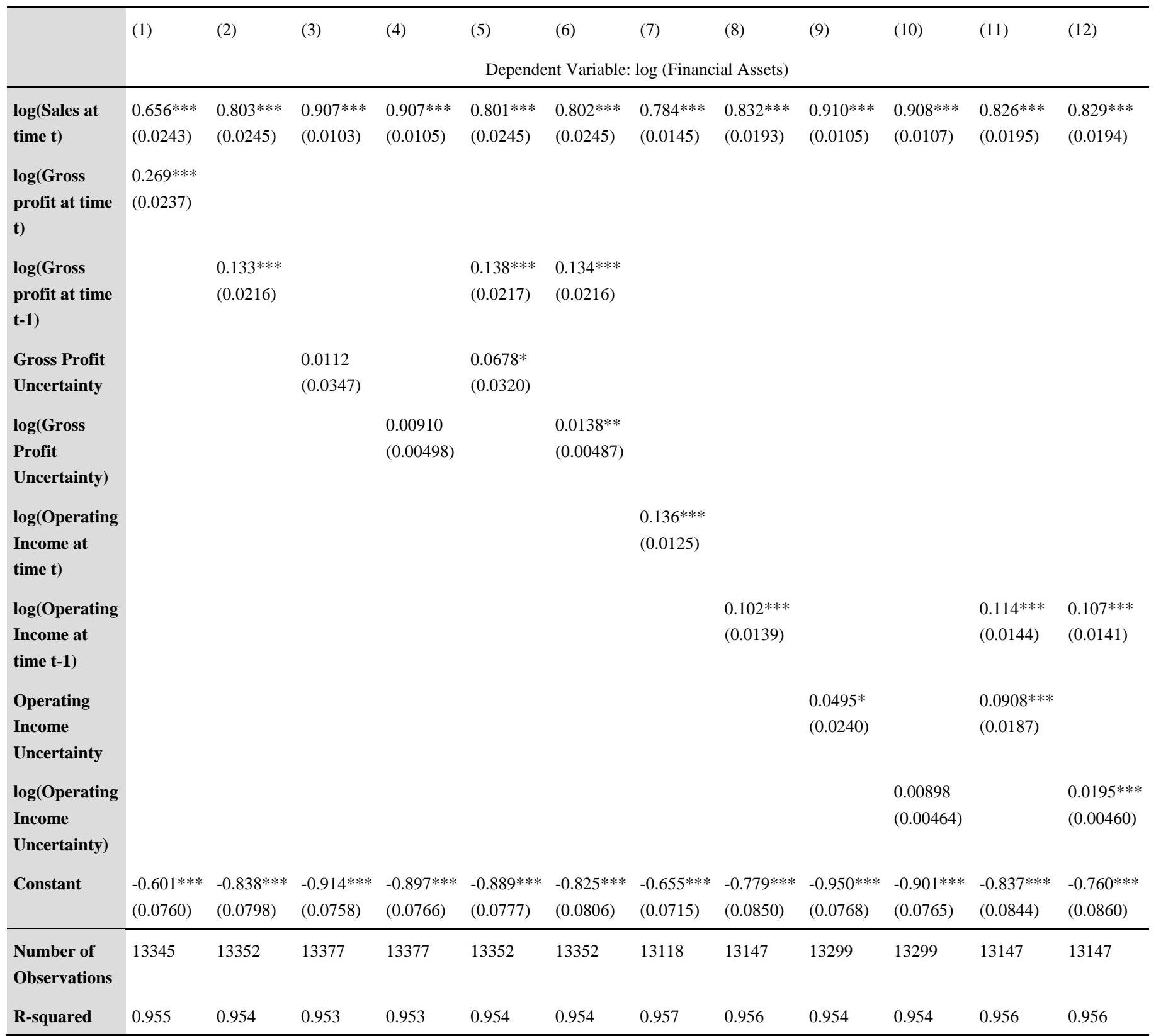

Note: Industry fixed effects and year fixed effects are included in all specifications in this table.

Standard errors in parentheses, * $\mathrm{p}<0.05 \quad * * \mathrm{p}<0.01 \quad * * * \mathrm{p}<0.001$. 
Table 8. Factor intensity, manufacturing sector only

\begin{tabular}{|c|c|c|c|c|c|c|c|c|c|c|c|c|}
\hline & (1) & $(2)$ & (3) & (4) & $(5)$ & (6) & (7) & (8) & (9) & $(10)$ & (11) & (12) \\
\hline & \multicolumn{12}{|c|}{ Dependent Variable: $\log$ (Financial Assets at time t) } \\
\hline $\begin{array}{l}\log (\text { Sales at time } \\
\text { t) }\end{array}$ & $\begin{array}{l}1.016^{* * *} \\
(0.0117)\end{array}$ & $\begin{array}{l}1.011 * * * \\
(0.0118)\end{array}$ & $\begin{array}{l}1.012 \text { *** } \\
(0.0118)\end{array}$ & $\begin{array}{l}1.016 * * * \\
(0.0117)\end{array}$ & $\begin{array}{l}1.011 * * * \\
(0.0118)\end{array}$ & $\begin{array}{l}1.013 * * * \\
(0.0118)\end{array}$ & $\begin{array}{l}1.017 * * * \\
(0.0117)\end{array}$ & $\begin{array}{l}1.011 * * * \\
(0.0118)\end{array}$ & $\begin{array}{l}1.013 * * * \\
(0.0118)\end{array}$ & $\begin{array}{l}1.017 * * * \\
(0.0117)\end{array}$ & $\begin{array}{l}1.011 * * * \\
(0.0118)\end{array}$ & $\begin{array}{l}1.013 * * * \\
(0.0118)\end{array}$ \\
\hline $\begin{array}{l}\log (\text { ratio between } \\
\text { Capital Stock } \\
\text { and Total Value } \\
\text { Added) }\end{array}$ & $\begin{array}{l}0.119 * * * \\
(0.0231)\end{array}$ & & & $\begin{array}{l}0.115 * * * \\
(0.0226)\end{array}$ & & & $\begin{array}{l}0.110 * * * \\
(0.0230)\end{array}$ & & & $\begin{array}{l}0.107 * * * \\
(0.0225)\end{array}$ & & \\
\hline $\begin{array}{l}\log (\text { ratio between } \\
\text { Capital Stock } \\
\text { and Total } \\
\text { Workers) }\end{array}$ & & $\begin{array}{l}0.246 * * * \\
(0.0218)\end{array}$ & & & $\begin{array}{l}0.237 * * * \\
(0.0208)\end{array}$ & & & $\begin{array}{l}0.249 * * * \\
(0.0218)\end{array}$ & & & $\begin{array}{l}0.239 * * * \\
(0.0209)\end{array}$ & \\
\hline $\begin{array}{l}\log (\text { ratio between } \\
\text { Capital Stock } \\
\text { and Total Payroll) }\end{array}$ & & & $\begin{array}{l}0.246 * * * \\
(0.0233)\end{array}$ & & & $\begin{array}{l}0.241 * * * \\
(0.0227)\end{array}$ & & & $\begin{array}{l}0.245^{* * *} \\
(0.0234)\end{array}$ & & & $\begin{array}{l}0.240 * * * \\
(0.0228)\end{array}$ \\
\hline $\begin{array}{l}\log (\text { share of } \\
\text { nonproduction } \\
\text { workers } \\
\text { in total } \\
\text { employment) }\end{array}$ & $\begin{array}{l}0.116^{*} \\
(0.0515)\end{array}$ & $\begin{array}{l}0.00164 \\
(0.0521)\end{array}$ & $\begin{array}{l}0.0641 \\
(0.0510)\end{array}$ & & & & $\begin{array}{l}0.122 * \\
(0.0518)\end{array}$ & $\begin{array}{l}-0.000748 \\
(0.0524)\end{array}$ & $\begin{array}{l}0.0657 \\
(0.0513)\end{array}$ & & & \\
\hline $\begin{array}{l}\log (\text { share of } \\
\text { income of } \\
\text { nonproduction } \\
\text { workers) }\end{array}$ & & & & $\begin{array}{l}0.206 * * * \\
(0.0608)\end{array}$ & $\begin{array}{l}0.103 \\
(0.0614)\end{array}$ & $\begin{array}{l}0.154 * \\
(0.0606)\end{array}$ & & & & $\begin{array}{l}0.213 * * * \\
(0.0618)\end{array}$ & $\begin{array}{l}0.0998 \\
(0.0620)\end{array}$ & $\begin{array}{l}0.155^{*} \\
(0.0614)\end{array}$ \\
\hline $\begin{array}{l}\log (\text { share of } \\
\text { Energy Costs in } \\
\text { Total Production) }\end{array}$ & $\begin{array}{l}-0.0769 * * \\
(0.0282)\end{array}$ & $\begin{array}{l}-0.0434 \\
(0.0276)\end{array}$ & $\begin{array}{l}-0.0630 * \\
(0.0277)\end{array}$ & $\begin{array}{l}-0.0747 * * \\
(0.0280)\end{array}$ & $\begin{array}{l}-0.0415 \\
(0.0275)\end{array}$ & $\begin{array}{l}-0.0611 * \\
(0.0276)\end{array}$ & & & & & & \\
\hline $\begin{array}{l}\text { Dummy variable } \\
\text { for High Energy } \\
\text { Share Industry }\end{array}$ & & & & & & & $\begin{array}{l}-0.209 * * * \\
(0.0613)\end{array}$ & $\begin{array}{l}-0.211 * * * \\
(0.0604)\end{array}$ & $\begin{array}{l}-0.208^{* * *} \\
(0.0598)\end{array}$ & $\begin{array}{l}-0.204 * * * \\
(0.0609)\end{array}$ & $\begin{array}{l}-0.204 * * * \\
(0.0598)\end{array}$ & $\begin{array}{l}-0.203 * * * \\
(0.0593)\end{array}$ \\
\hline Constant & $\begin{array}{l}-3.085^{* * *} \\
(0.218)\end{array}$ & $\begin{array}{l}-3.812 * * * \\
(0.227)\end{array}$ & $\begin{array}{l}-3.332 * * * \\
(0.213)\end{array}$ & $\begin{array}{l}-2.963 * * * \\
(0.206)\end{array}$ & $\begin{array}{l}-3.609 * * * \\
(0.213)\end{array}$ & $\begin{array}{l}-3.193^{* * *} \\
(0.202)\end{array}$ & $\begin{array}{l}-2.615^{* * *} \\
(0.141)\end{array}$ & $\begin{array}{l}-3.567 * * * \\
(0.170)\end{array}$ & $\begin{array}{l}-2.957 * * * \\
(0.145)\end{array}$ & $\begin{array}{l}-2.509 * * * \\
(0.137)\end{array}$ & $\begin{array}{l}-3.375^{* * *} \\
(0.161)\end{array}$ & $\begin{array}{l}-2.830 * * * \\
(0.141)\end{array}$ \\
\hline $\begin{array}{l}\text { Number of } \\
\text { Observations }\end{array}$ & 4463 & 4463 & 4463 & 4463 & 4463 & 4463 & 4463 & 4463 & 4463 & 4463 & 4463 & 4463 \\
\hline R-squared & 0.965 & 0.966 & 0.965 & 0.965 & 0.966 & 0.965 & 0.965 & 0.966 & 0.965 & 0.965 & 0.966 & 0.965 \\
\hline
\end{tabular}

Note: Industry fixed effects and year fixed effects are included in all specifications in this table.

Standard errors in parentheses, $* \mathrm{p}<0.05 \quad * * \mathrm{p}<0.01 \quad * * * \mathrm{p}<0.001$.

\section{Conclusions}

This paper examines financialization of non-financial industries in the United States, contributing to recent scholarly efforts to highlight more variegated facets of financialization. It identifies a significant variation in the shares of financial income among different non-financial industries from 1980 to 2006. A closer look further reveals that financialization is closely related to industry-level uncertainty. Important historical events and policy changes such as oil shock and deregulation facilitated industrywide industrial restructuring and financialization in the oil, chemical manufacturing, and communications sectors. 
Our statistical analysis complements the preceding historical observation. It finds that industry-level factors have high explanatory power regarding interindustry variation in financial assets: profitability, uncertainty, skill intensity, capital intensity, and energy intensity. Contrary to the prevailing notion, operating profit is positively correlated with financialization. Industries with higher real profits are more likely to acquire financial assets in the following year. The result implies that real and financial investments are not in a zero-sum relationship. Moreover, the relationship may depend on the financial constraints a firm faces. Some studies suggest that firms in developed economies have relatively easy access to credit, while firms in emerging economies do not, due to capital market imperfections (Kliman and Williams 2015; Demir 2009). A broader implication is that the mechanisms through which profitability affects financialization may vary across countries, industries, and firms. Future research needs to focus on explicating specific conditions under which profitability supports or suppresses financialization.

Industry-level uncertainty is positively associated with financialization, corroborating earlier empirical research on macroeconomic uncertainty and firm-level volatility (Akkemik and Özen 2014; Bates, Kahle, and Stulz 2009). The statistical result is also coherent with our historical analysis of a few selected industries regarding historical and institutional shocks and industry-level financialization. In times of high uncertainty, firms seem to prefer short-term liquid financial investments over long-term, irreversible investments. In addition to profitability and uncertainty, we shed light on a set of determinants that financialization studies have yet to examine: factor intensity. We find that manufacturing industries with higher skill intensity, higher capital intensity, and lower energy intensity are more financialized. Our interpretation is that industries with longer investment horizons acquire financial assets to compensate for risks involved in long-term and irreversible capital investment. We do not suggest that these industries substitute financial investment for real investment. Instead, profits from financial operations can serve as a pacifier to placate impatient investors' demands for quick returns, given the shareholder value mantra in the United States. One limitation of this study is the sample period which covers up to the year 2006. While this research represents a good beginning, we hope to see further research on post-2008 financial crisis in order to provide a fuller picture of financialization of NFF.

All in all, this research underlines how different industries, reflecting their unique historical experiences and productive features, exhibit distinctive degrees and patterns of financialization.

\section{References}

Akkemik, K. A., \& Özen, S. (2014). Macroeconomic and Institutional Determinants of Financialisation of Non-Financial Firms: Case Study of Turkey. Socio-Economic Review, 12(1), 71-98.

Arrighi, G. (1994). The Long Twentieth Century: Money, Power, and the Origins of Our Times. London; New York: Verso.

Barradas, R., \& Lagoa, S. (2017). Financialization and Portuguese Real Investment: A Supportive or Disruptive Relationship?. Journal of Post Keynesian Economics, 40(3), 413-39.

Bates, T. W., Kahle, K. M., \& Stulz, R. M. (2009). Why Do U.S. Firms Hold so Much More Cash than They Used To?. The Journal of Finance, 64(5), 1985-2021.

Baud, C., \& Durand, C. (2012). Financialization, Globalization and the Making of Profits by Leading Retailers. Socio-Economic Review, 10(2), 241-66.

Becker, J., Jäger, J., Leubolt, B., \& Weissenbacher, R. (2010). Peripheral Financialization and Vulnerability to Crisis: A Regulationist Perspective. Competition \& Change, 14(3-4), 225-47.

Blair, M. M., \& Uppal, G. (1993). The Deal Decade Handbook. Washington, D.C. : Brookings Institution, c1993.

Crotty, J. (2005). The Neoliberal Paradox: The Impact of Destructive Product Market Competition and 'Modern' Financial Market on Non-financial Corporation Performance in the Neoliberal Era. In G. A. Epstein (Ed.), Financialization and the World Economy. Edward Elgar Publishing.

Davis, G. F. (2009). Managed by the Markets: How Finance Reshaped America. Oxford; New York: Oxford University Press.

Davis, L. E. (2016). Identifying the 'Financialization' of the Non-financial Corporation in the US Economy: A Decomposition of Firm-Level Balance Sheets. Journal of Post Keynesian Economics, 39(1), 115-41.

Davis, L. E. (2017). Financialization And Investment: A Survey Of The Empirical Literature. Journal of Economic Surveys, 31(5), 1332-58. 
Davis, L. E. (2018). Financialization and the Non-Financial Corporation: An Investigation of Firm-Level Investment Behavior in the United States. Metroeconomica, 69(1), 270-307.

Demir, F. (2009). Financialization and Manufacturing Firm Profitability under Uncertainty and Macroeconomic Volatility: Evidence from an Emerging Market. Review of Development Economics, 13(4), 592-609.

Demir, F. (2009). Financial Liberalization, Private Investment and Portfolio Choice: Financialization of Real Sectors in Emerging Markets. Journal of Development Economics, 88(2), 314-24.

Epstein, G. A. (2005). Financialization and the World Economy. Edward Elgar Publishing.

Hall, B. H. (1994). Corporate Restructuring and Investment Horizons in the United States, 1976-1987. The Business History Review, 68(1), 110-43.

Hein, E. (2015). Finance-Dominated Capitalism and Re-Distribution of Income: A Kaleckian Perspective. Cambridge Journal of Economics, 39(3), 907-34.

Kliman, A., \& Williams, S. D. (2015). Why 'Financialisation' Hasn't Depressed US Productive Investment. Cambridge Journal of Economics, 39(1), 67-92.

Krippner, G. R. (2011). Capitalizing on Crisis: The Political Origins of the Rise of Finance. Cambridge, Mass: Harvard University Press.

Lane, S. (1993). Corporate Restructuring in the Chemicals Industry. In M. M. Blair (Ed.), The Deal Decade: What Takeovers and Leveraged Buyouts Mean for Corporate Governance. Washington, D.C.: Brookings Institution.

Lazonick, W., \& O'Sullivan, M. (2000). Maximizing Shareholder Value: A New Ideology for Corporate Governance. Economy and Society, 29(1), 13-35.

Lin, K-H., \& Tomaskovic-Devey, D. (2013). Financialization and U.S. Income Inequality, 1970-2008. American Journal of Sociology, 118 (5), 1284-1329.

Mitchell, M. L., \& Mulherin, J. H. (1996). The Impact of Industry Shocks on Takeover and Restructuring Activity. Journal of Financial Economics, 4(2), 193-229.

Onaran, O., Stockhammer, E., \& Grafl, L. (2011). Financialisation, Income Distribution and Aggregate Demand in the USA. Cambridge Journal of Economics, 35(4), 637-61.

Orhangazi, Ö. (2008). Financialization and the US Economy. New Directions in Modern Economics. Cheltenham, UK ; Northampton, MA: Edward Elgar.

Seo, H-J., Kim, H. S., \& Kim, J. (2016). Does Shareholder Value Orientation or Financial Market Liberalization Slow Down Korean Real Investment?. Review of Radical Political Economics, 48(4), 633-60.

Soener, M. (2015). Why Do Firms Financialize? Meso-Level Evidence from the US Apparel and Footwear Industry, 1991-2005. Socio-Economic Review, 13(3), 549-73.

Stockhammer, E. (2004). Financialisation and the Slowdown of Accumulation. Cambridge Journal of Economics, 28(5), 719-41.

Stockhammer, E. (2005). Shareholder Value Orientation and the Investment-Profit Puzzle. Journal of Post Keynesian Economics, 28(2), 193-215.

Tomaskovic-Devey, D., Lin, K-H., \& Meyers, N. (2015). Did Financialization Reduce Economic Growth?. Socio-Economic Review, 13(3), 525-48.

Tori, D., \& Onaran, Ö. (2018). The Effects of Financialization on Investment: Evidence from Firm-Level Data for the UK. Cambridge Journal of Economics, 42(5), 1393-1416.

Wall Street Journal (1923 - Current File); New York, N.Y. (1978). Chemical Firm Profits Squeezed In 2nd Quarter: Monsanto's Net Fell 6.6\%; Union Carbide Had 4\% Gain on 11\% Sales Rise, July 21, 1978, sec. 1.

. (1979). Monsanto Is Set to Buy Radiation Dynamics For About \$25 Million, December 20, 1979, sec. 1.

Watkins, J. P. (2017). Financialization and Society's Protective Response: Reconsidering Karl Polanyi's Double Movement. Journal of Economic Issues, 51(1), 98-117.

Wigmore, B. A. (1997). Securities Markets in the 1980s. New York: Oxford University Press. 
Writer, Nell Henderson Washington Post Staff. (1985). Monsanto to Buy G.D. Searle \& Co.: \$2.7 Billion Deal Gives Diversified Chemicals Conglomerate Entry Into Pharmaceuticals Monsanto Co. Agrees to Buy G.D. Searle. The Washington Post (1974-Current File), Washington, D.C., July 19, 1985, sec. BUSINESS.

W.T. Grimm \& Co. Mergerstat Review. Chicago, Il.: W.T. Grimm \& Co.

Zezza, G. (2018). Introduction to the Special Issue on Financialization, Growth and Distribution. Journal of Post Keynesian Economics, 41(2), 161-64.

Zwan, N. van der. (2014). Making Sense of Financialization. Socio-Economic Review, 12(1), 99-129.

\section{Notes}

Note 1. In this paper, we focus on one aspect of financialization of non-financial firms: growing reliance on financial income. Other aspects include growing payments to financial actors (e.g. dividends, share buybacks) and the shift in corporate governance favoring shareholders.

Note 2. For instance, Mitchell and Mulherin (1996) show that important economic shocks such as energy crisis, deregulation, and financing innovations led to different levels of takeover and restructuring across 51 industries between 1982-1989 in the United States.

Note 3. We consider as financial sector the industries of SIC codes from 6000 to 6799.

Note 4. Scholars have examined "financial income" and "financial assets" of non-financial firms to analyze financialization of non-financial firms. Since IRS does not provide "financial assets" data, we used "financial income" in this section. The IRS data is useful for our analysis of broad historical trends given its reliability and comprehensiveness.

Note 5. Specifically, companies planning to acquire other firms often retain past earnings, instead of using them to finance real investment, leading to an increase in financial reserves. Also, when firms sell off product lines, the divestment can generate a huge increase in financial assets.

Note 6. For instance, air transport, which aggregated with truck, pipeline transportation and warehousing under transportation prior to 1998, became a separate unit under the transportation sector after 1998. Accordingly, the IRS data does not allow us to capture, for example, the impact of deregulation in the air transport sector in the late 1970s and early 1980s (Mitchell and Mulherin 1996).

Note 7. We follow Davis (2016) definition of financial assets. She systematically examines the evidence for the financialization of non-financial corporations (NFC) by investigating the share of financial assets in NFC portfolios.

Note 8. This is analogous to Soener's (2015) specification that controls for the scale of firms to estimate the effects of certain variables on financial investments. We tested both the number of employees and the amount of sales, concluding that sales show a stronger positive relationship with financial investment than employment does (Table 6). Accordingly, we control the sales variable in all regression models throughout this paper.

Note 9. We follow Mitchell and Mulherin (1996) conceptualization and measure of uncertainty to capture industry-level volatility.

Note 10. Notably, this analysis does not examine relative rates of return. That is, an improvement in real profitability relative to an improvement in financial profitability may lead to a portfolio reallocation against financial assets. This topic merits further exploration. 


\section{Appendix A}

\section{Summary Statistics, Compustat, All Nonfinancial Industries}

\begin{tabular}{|c|c|c|c|c|c|}
\hline & Observations & Mean & Std. deviation & Minimum & Maximum \\
\hline Financial Assets & 13402 & 580.3045 & 2758.517 & 0 & 87373.03 \\
\hline Cash and Short-Term & 13402 & 103.3914 & 427.0988 & 0 & 9289.368 \\
\hline Receivables & 13402 & 223.1263 & 1137.524 & 0 & 41017.46 \\
\hline Investment and Advances - & 13402 & 38.51946 & 199.3731 & -1.834944 & 6094.857 \\
\hline Investment and Advances - & 13402 & 81.32075 & 709.0642 & 0 & 23153.48 \\
\hline Current Assets & 13402 & 41.73983 & 171.5682 & 0 & 4433.018 \\
\hline Other Assets & 13402 & 92.2068 & 487.6696 & -5.631857 & 27185.91 \\
\hline Employment & 13402 & 7.518657 & 15.34258 & 0 & 204.4977 \\
\hline Sales & 13402 & 1289.917 & 3782.406 & 0 & 68399.27 \\
\hline Gross Profit & 13402 & 354.9005 & 1023.81 & -192.1254 & 16891.14 \\
\hline Operating Income & 13402 & 163.2942 & 502.9627 & -439.6346 & 13768.85 \\
\hline Standard Deviation of & 13393 & .1883083 & .2648701 & 0 & 4.982395 \\
\hline Standard Deviation of Sales & 13400 & .1852567 & .2313699 & .0005957 & 5.389094 \\
\hline Standard Deviation of Gross & 13396 & .1999519 & .2407463 & .0007076 & 5.470724 \\
\hline Standard Deviation of & 13313 & .2725377 & .3102757 & .0000366 & 4.577986 \\
\hline $\log$ (Financial Assets) & 13387 & 4.638537 & 1.736103 & -3.296837 & 11.37794 \\
\hline $\log ($ Cash and Short-Term & 13382 & 2.872277 & 1.801543 & -7.600903 & 9.136626 \\
\hline $\log ($ Receivables $)$ & 13370 & 3.750442 & 1.737237 & -6.214608 & 10.62175 \\
\hline $\log$ (Investment and & 10126 & 1.084766 & 2.68762 & -9.21034 & 8.7152 \\
\hline $\log (($ Investment and & 11903 & 1.191132 & 2.559862 & -8.987197 & 10.0499 \\
\hline $\log$ (Current Assets) & 13362 & 1.78426 & 1.988465 & -7.061906 & 8.396836 \\
\hline $\log$ (Other Assets) & 13368 & 2.245877 & 2.181255 & -7.600903 & 10.21045 \\
\hline $\log$ (Employment) & 13351 & .9837689 & 1.49415 & -7.313221 & 5.320557 \\
\hline $\log ($ Sales $)$ & 13383 & 5.738995 & 1.678349 & -7.600903 & 11.13312 \\
\hline $\log$ (Gross Profit) & 13346 & 4.48088 & 1.663896 & -5.809143 & 9.734545 \\
\hline $\log ($ Operating Income $)$ & 13118 & 3.584828 & 1.793591 & -5.809143 & 9.530164 \\
\hline Total Observations & 13402 & & & & \\
\hline
\end{tabular}




\section{Appendix B}

Summary Statistics, NBER, Manufacturing Sector Only

\begin{tabular}{|c|c|c|c|c|c|}
\hline & Observations & Mean & Std. deviation & Minimum & Maximum \\
\hline Financial Assets & 4523 & 610.8994 & 2559.146 & 0 & 46504.8 \\
\hline $\begin{array}{l}\text { Share of Number of } \\
\text { Nonproduction Workers in } \\
\text { Total Employment }\end{array}$ & 4469 & .331236 & .1453722 & .061436 & .8639004 \\
\hline $\begin{array}{l}\text { Share of Income of } \\
\text { Nonproduction Workers in } \\
\text { Total Payroll }\end{array}$ & 4469 & .4316734 & .1579155 & .122834 & .8970615 \\
\hline $\begin{array}{l}\text { Ratio between Capital Stock } \\
\text { and Total Value Added }\end{array}$ & 4469 & 1.075291 & .8278885 & .1411151 & 11.87562 \\
\hline $\begin{array}{l}\text { Ratio between Capital Stock } \\
\text { and Total Workers }\end{array}$ & 4469 & 92.55053 & 116.1297 & 9.002782 & 1229.537 \\
\hline $\begin{array}{l}\text { Ratio between Capital Stock } \\
\text { and Total Payroll }\end{array}$ & 4469 & 3.134798 & 2.758573 & .498942 & 33.45935 \\
\hline Share of Energy Costs & 4469 & .0102211 & .0158052 & .0006473 & .1439396 \\
\hline $\begin{array}{l}\text { Dummy for High Energy Share } \\
\text { Industry }\end{array}$ & 4523 & .0214459 & .1448815 & 0 & 1 \\
\hline $\log$ (Financial Assets) & 4517 & 4.70709 & 1.75966 & -3.244194 & 10.74731 \\
\hline $\begin{array}{l}\log \text { (Share of Nonproduction } \\
\text { Workers in Total Employment) }\end{array}$ & 4469 & -1.201051 & .4452124 & -2.78976 & -.1462978 \\
\hline $\begin{array}{l}\log (\text { Share of Income of } \\
\text { Nonproduction Workers in } \\
\text { Total Payroll })\end{array}$ & 4469 & -.9096611 & .3806845 & -2.096921 & -.1086308 \\
\hline $\begin{array}{l}\log \text { (Ratio between Capital Stock } \\
\text { and Total Value Added) }\end{array}$ & 4469 & -.1238337 & .5992342 & -1.958179 & 2.474488 \\
\hline $\begin{array}{l}\log \text { (Ratio between Capital Stock } \\
\text { and Employment) }\end{array}$ & 4469 & 4.126581 & .8181032 & 2.197534 & 7.114393 \\
\hline $\begin{array}{l}\log ((\text { Ratio between Capital } \\
\text { Stock and the Total Payroll })\end{array}$ & 4469 & .915564 & .6271199 & -.6952654 & 3.510331 \\
\hline $\log$ (Share of Energy Costs) & 4469 & -5.009754 & .7755746 & -7.342658 & -1.938361 \\
\hline Total Observations & 4523 & & & & \\
\hline
\end{tabular}

\section{Copyrights}

Copyright for this article is retained by the author(s), with first publication rights granted to the journal.

This is an open-access article distributed under the terms and conditions of the Creative Commons Attribution license (http://creativecommons.org/licenses/by/4.0/). 